\title{
Thermal waters of central Poland: a case study from Mogilno-Łódź Trough, Poland
}

\author{
Anna Sowiżdżał ${ }^{1}$ Marek Hajto ${ }^{1} \cdot$ Elżbieta Hałaj $^{1}$ (C)
}

Received: 3 June 2019 / Accepted: 11 February 2020 / Published online: 28 February 2020

(c) The Author(s) 2020

\begin{abstract}
Thermal waters in Poland occur in several different geothermal regions, but the best parameters for their effective utilisation are connected i.a. with the area of Polish Lowlands. One of the most prospective areas in the central part of Polish Lowlands for managing geothermal waters for various purposes is the area of Mogilno-Łódź Trough. There are currently 2 operating geothermal heating plants and several others in various stages of development. In this area, water with a temperature of $97.5^{\circ} \mathrm{C}$ has been documented. The aim of this article is to determine and visualise the potential of geothermal waters of the central Poland (Mogilno-Łódź Trough) by providing the most important, potential geothermal water parameters. It is done by providing maps of potential temperature, mineralization, water outflow capacity, thermal power and physicochemical analysis (mineralization, waters type). The two most prospective geothermal reservoirs-Lower Jurassic and Lower Cretaceous - were analysed. The results of the studies indicate that this area is characterised by very favourable hydrogeological conditions. Geothermal energy utilisation should be connected with Lower Jurassic and Lower Cretaceous reservoirs, but it should be emphasised that a larger energy potential relates to waters from Lower Jurassic reservoir; however, they are characterised by high water mineralisation (up to $170 \mathrm{~g} / \mathrm{L}$ ). Waters of Lower Cretaceous reservoir are characterised by not only lower mineralisation (up to $100 \mathrm{~g} / \mathrm{L}$ ), but also lower temperature (max. $75^{\circ} \mathrm{C}$ ). The highest temperatures in the Lower Jurassic are recorded in the axial part of the Trough, where, locally, they exceed in the top of formation $100{ }^{\circ} \mathrm{C}$. On the other hand, in edge Trough zones, water temperatures are $30-40{ }^{\circ} \mathrm{C}$. The actual geothermal potential of the area is much higher than currently used. For example, potential discharge of wells is to over $400 \mathrm{~m}^{3} / \mathrm{h}$ in the Lower Cretaceous and up to over $500 \mathrm{~m}^{3} / \mathrm{h}$ in the Lower Jurassic.
\end{abstract}

Keywords Geothermal reservoirs · Thermal parameters · Lower Jurassic · Lower Cretaceous · Poland

\section{Introduction}

Distribution of geothermal resources is uneven in the world. Particularly favourable conditions for the creation of highenergy geothermal systems, which are potentially the best for industrial applications, occur in the area of lithospheric

This article is a part of the Topical Collection in Environmental Earth Sciences on "Mineral and Thermal Waters" guest edited by Drs. Adam Porowski, Nina Rman and Istvan Forizs, with James LaMoreaux as the Editor-in-Chief.

Elżbieta Hałaj

elzbieta.halaj@gmail.com

1 Department of Fossil Fuels, Faculty of Geology, Geophysics and Environmental Protection, AGH University of Science and Technology, al. A. Mickiewicza 30, 30-059 Kraków, Poland plates in rift and subduction zones. Poland is located outside of those zones, which means that there are no high-temperature geothermal resources on its area. Poland is located in the zone of low-temperature resources, for which heating is the key sector. Water temperature documented with geothermal wells does not exceed $100{ }^{\circ} \mathrm{C}$. Presently, the highest temperature of geothermal water in the Polish Lowland, where water reserves were identified, was reported in Konin (the city in the area of Mogilno-Łódź Trough). The temperature of geothermal water in Lower Jurassic reservoir at the end depth of $2660 \mathrm{~m}$ reaches $97.5^{\circ} \mathrm{C}$, with mineralisation of $150 \mathrm{~g} / \mathrm{L}$ and high capacity of around $150 \mathrm{~m}^{3} / \mathrm{h}$ (Sowiżdżał et al. 2017).

The aim of this article is to show the potential of geothermal waters of the central Poland by providing the potential and the most important geothermal water parameters. It is done by providing maps of potential temperature, 
mineralization, water outflow capacity, thermal power and physicochemical analysis (mineralization, waters type). Analysis is done for the two most favourable formations in the Mogilno-Łódź Trough, central Poland.

Geothermal conditions in Poland are relatively well recognised. Geothermal studies have been conducted in Poland since 1980s. Comprehensive information about Poland's geothermal resources is provided by a series of Geothermal Atlases, covering the areas of the Polish Lowland, Carpathians and the Carpathian Foredeep (Górecki et al. 2006a, b, 2011, 2012, 2013, 2015; Haenel and Hurter 2002; Sowiżdżał 2018). These works indicate the possibilities of using hydrogeothermal resources mainly for not only heating purposes, but also balneotherapy, recreation and the like. They have been supplemented by Atlas of geothermal water use in energy cogeneration in binary systems in Poland (Bujakowski et al. 2014) published in 2014, indicating the opportunities of using the existing low-temperature resources in the selected regions of Poland for the production of electricity, which are not fulfilled in Poland at the moment. In the Polish Lowland, special attention should be drawn to the area of Mogilno-Łódź Trough, where there are prospects for the effective use of geothermal resources for energy purposes (both heating and electricity production in binary systems) and building of Enhanced Geothermal Systems (EGS) in sedimentary rocks (Wójcicki et al. 2013; Sowiżdżał et al. 2013; Sowiżdżal and Kaczmarczyk 2016). Nevertheless, regardless the waters are thermal waters or they have lower temperatures, the water or the reservoir still could be used within shallow geothermal, heat pumps and for aquifer thermal energy storage (Halaj 2017; Halaj and Kepińska 2018).

In recent years, on the basis of regional exploration of hydrogeothermal properties in the area of Mogilno-Łódź Trough, several new places were pointed, which are characterised by favourable reservoir parameters for geothermal waters. All of them confirm excellent geothermal parameters of both Lower Cretaceous and Lower Jurassic aquifers. The area of Mogilno-Eódź Trough was also the subject of the geothermal parameters evaluation from the results of seismic survey (Maćkowski et al. 2019; Sowiżdżał et al. 2019).

In some cases, wells discharge may be even as high as $300 \mathrm{~m}^{3} / \mathrm{h}$, which is confirmed by hydrogeological studies of Lower Cretaceous reservoir performed in 2015 in Poddębice (Posyniak 2015). Approved exploitable reserves of the Poddębice GT-2 geothermal water capture amount to $252 \mathrm{~m}^{3} / \mathrm{h}$ at a dynamic water table at a depth of $85.3 \mathrm{~m} \mathrm{b.g.1.}$ and the water wellhead temperature $71{ }^{\circ} \mathrm{C}$. Lower Cretaceous aquifer was also recognised well in the area of Uniejów, where, in 1970s, groundwaters with the temperature of $68{ }^{\circ} \mathrm{C}$ were drilled, thus confirming the occurrence of geothermal waters within Lower Cretaceous formations. Further wells drilled in 1990s documented waters characterised by the outflow of around $90 \mathrm{~m}^{3} / \mathrm{h}$ and the temperature of ca. $70{ }^{\circ} \mathrm{C}$. Reservoir rocks build Lower Cretaceous sandstones located at the depth of ca, 1.9-2.0 km. In 2005, abstraction of geothermal waters was approved by means of a submersible pump with a volume flow at the level of $120 \mathrm{~m}^{3} / \mathrm{h}$ (Sapińska-Śliwa 2011; Kępińska et al. 2017). In both places, there is an intensive geothermal water exploitation, both for space heating and for balneorecreation and balneotherapy (Halaj 2015).

\section{Geological background}

The area of Mogilno-Łódź Trough, in its geological evolution, initially constituted a part of Mid-Polish Trough. As a result of Laramian movements, the trough was transformed into the Central Poland anticlinorium. Lower Cretaceous sediments with the biggest thickness have been preserved along the anticlinorium edge, including also the area of Mogilno-Łódź synclinorium (Mizerski 2011). This synclinorium is a paleo-depression, where the top of Lower Cretaceous formations is lied at the depth from 0 (outcrop area-a SW part) to over $2800 \mathrm{~m}$ below ground level. It is a part of a bigger structure, which covers most of the Poland territory - the Polish Lowlands (Fig. 1) (Dadlez et al. 2000).

Thickness differentiation of particular stratigraphic groups in the area of the Trough (including Lower Cretaceous and Lower Jurassic formations) relates to disjunctive tectonics and Zechstein salt movements in the bedrock. In this area there are several dislocation zones. One of the fundamental dislocation zones is located in the northeastern part of the area (Narkiewicz and Dadlez 2008). Mogilno-Łódź Trough is filled with Upper Cretaceous sediments lying on older rocks arising on the sub-Cenozoic surface in south-western wing of the Middle-Poland Ridge and on Fore-Sudetic Monocline and on elevations (Stupnicka 1997; Mizerski 2011). The Permo-Mesozoic cover (Fig. 2) made up by the sediments filling Mogilno-Łódź Trough lies on older sediments: Rotliegend, Upper Carboniferous, Lower Carboniferous, Devonian, Silurian, Ordovician and Cambrian deposited on crystalline and volcanic rocks of Pre-Cambrian substrate. Variscan orogeny units (Variscan externides) are poorly recognised on this area, due to a very large thickness of the Permo-Mesozoic cover (Karnkowski 1980; Dadlez et al. 2000; Narkiewicz and Dadlez 2008; Mizerski 2011).

\section{Materials and methods}

To identify possibilities of occurrence of favourable geothermal waters conditions in the area of Mogilno-Łódź Trough, the analysis of geological and hydrogeothermal parameters 
Fig. 1 Location of research area on the background of geological map without Cenozoic formations (on the basis of Dadlez et al. 2000)

Fig. 2 Geological cross section through Mogilno-_ódź Trough (acc. to Karnkowski 1980; Gorecki and Hajto (eds.) et al. 2006a)—simplified, cross-section line visible in Fig. 3
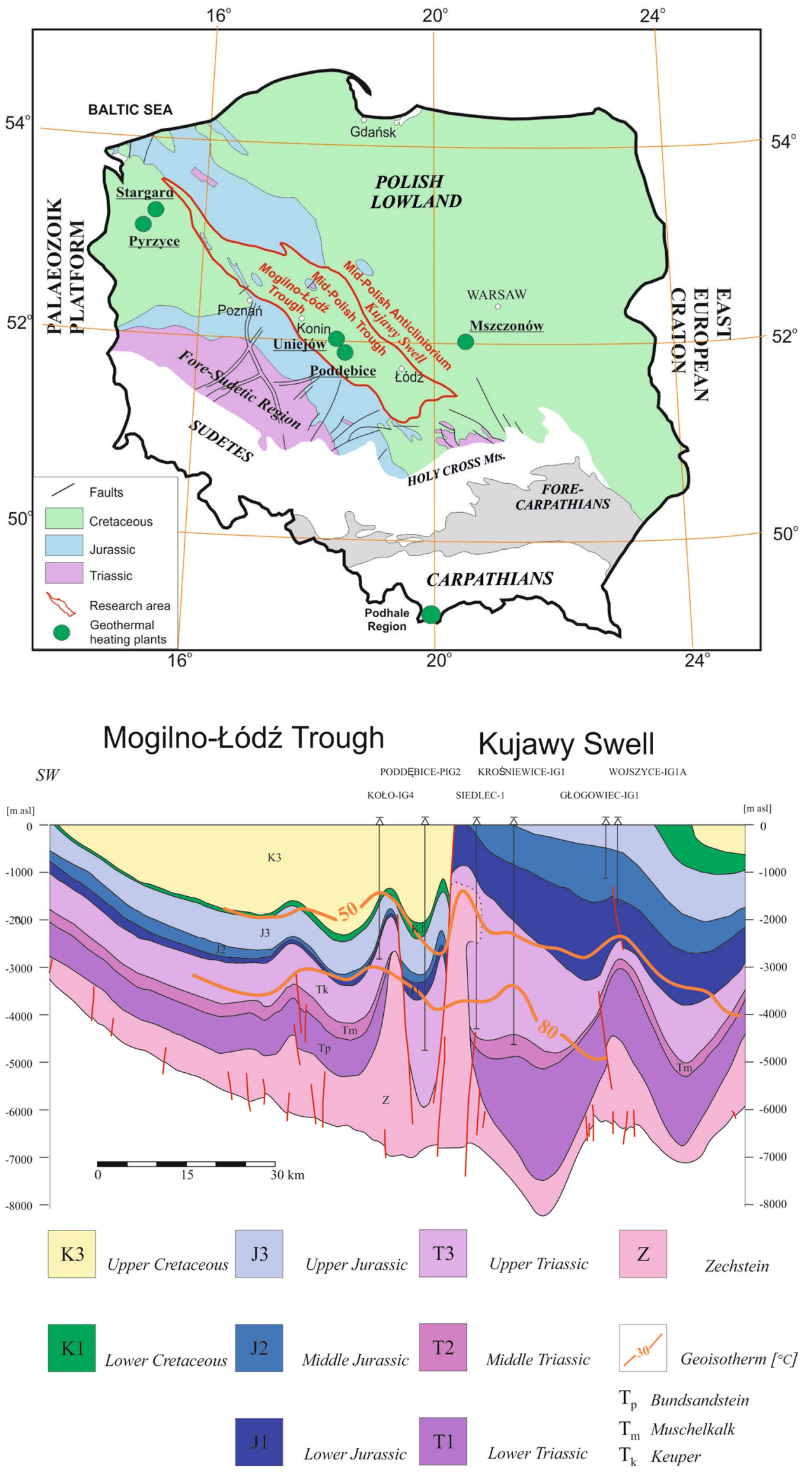
for a Lower Cretaceous and Lower Jurassic geothermal reservoir was conducted on the basis of the analysis of archival materials, research works, geological projects of operational parameters of geothermal installations. These reservoirs are considered to be the most prospective in the area (Gorecki et al. 2006a). Hydrogeological and geothermal parameters were evaluated, including estimation of water temperatures and mineralisation, as well as discharge capacities in the area of geothermal reservoirs being analysed.

The area under analyses is recognised with exploratory and reservoir drilling profiles, oriented mainly towards oil potential explorations in the Polish Lowland. Based on data collected in Central Geological Database (CBDG 2019), over 20,000 wells have been located in the area of Mogilno-Łódź Trough, including exploratory, cartographic, geological engineering as well as reservoir and hydrogeological wells with variable depths. The usefulness of information included in well-related documentation, including data collected in CBDG, to evaluate geothermal potential depends on a number of factors. One of them, obviously regardless of the quality of the included information, is the wells depth. From the point of view of evaluating geothermal water potential and management, data coming from deep drilling wells are particularly valuable. The analysis of collected archival data shows that 115 wells with the depth exceeding $1500 \mathrm{~m}$ were located in the area of the Trough. Only 7 wells have the final depth over $3000 \mathrm{~m}$ below ground level. The location of drilling wells in the area of Mogilno-Łódź Trough has been presented in Fig. 3 .

Data from deep wells were the main source of information for thermal and physicochemical characterization of waters from Lower Cretaceous and Lower Jurassic geothermal reservoirs. For the purpose of geothermal model construction, thermal logs from 14 wells, located on the study area, were used. Most of them were taken under quasi-steady-state conditions to assure true temperatures of rocks. Those temperature measurements represented a direct source of information on the subsurface thermal regime. It is well known that the subsurface temperature measurements, even when done with proper care, are
Fig. 3 Location of deep wells $(>1000 \mathrm{~m})$ in the research area and surrounding areas

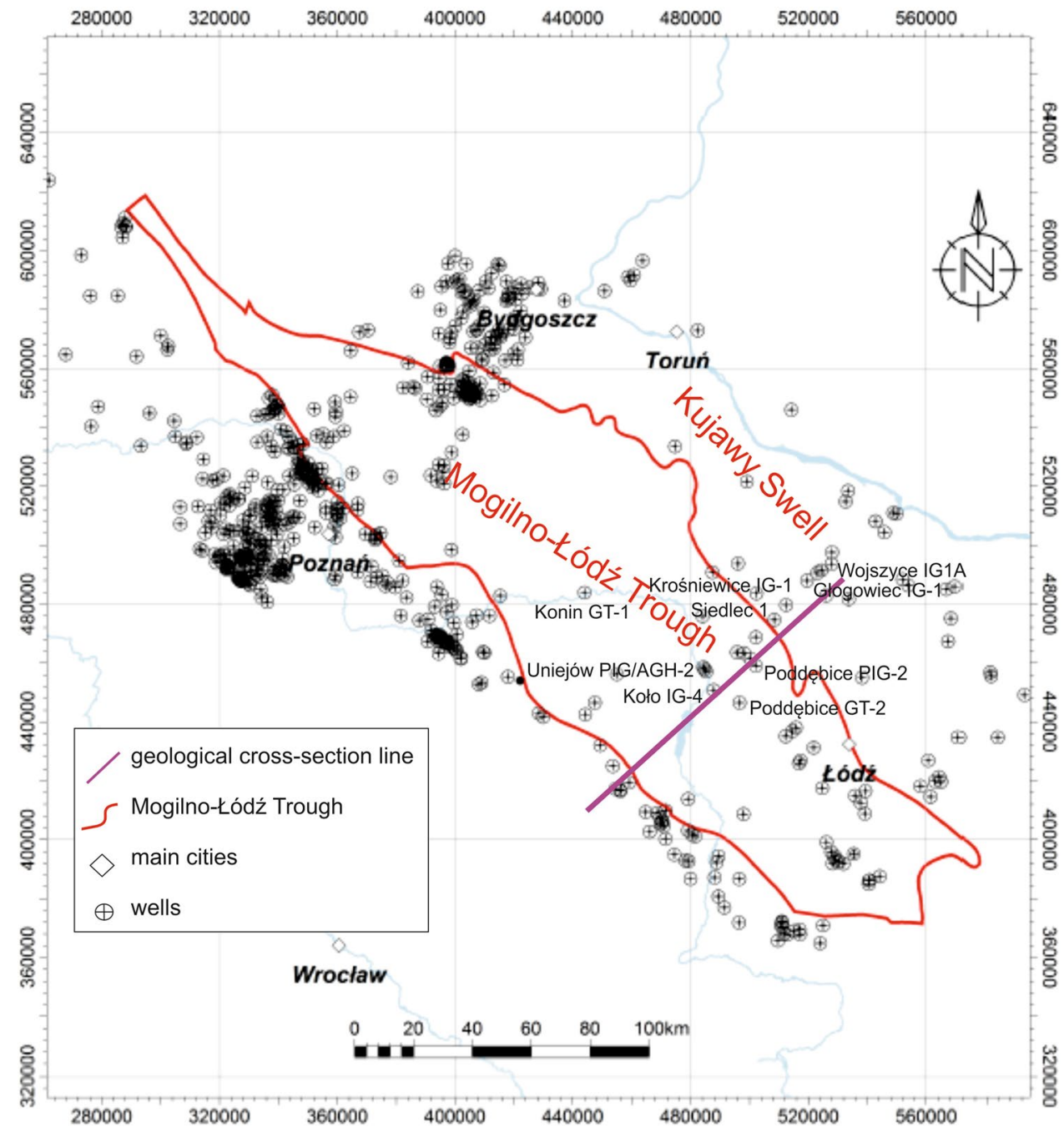


affected by a number of errors. Disturbance of natural thermal regime of rocks caused by drilling operations, mostly by long-lasting circulation of drilling mud, significantly changes the temperatures recorded along the wellbore. Disturbances are most visible in the upper and bottom parts of the profile; the upper is overheated, while the lower is cooled down. Completion of drilling initiates the long-lasting process of stabilisation, when thermal regime returns back to the natural state. However, the possible vertical convection of drilling mud in the well forced by temperature gradients between various parts of the well may cause that the disturbances are practically irreversible. An important indicator of stability of thermal measurements is the rough consistency between temperatures recorded in the sub-surface zone of the wellsite and those measured in the adjacent areas.

To perform physicochemical characteristics of waters, ca. 150 wells were analysed, which contained in their profile Lower Cretaceous and Lower Jurassic formations. Only those wells were taken for further analysis, where water was present and was analysed at least in the area of mineralisation and main ions. Finally, 37 wells for Lower Cretaceous and 25 wells for Lower Jurassic were chosen.

Waters that occurred in analysed wells not always were a subject of precise analysis (only for dozens of wells there is data from test pumping). In case of water occurrence, for most of the wells, only main ions and mineralization of water were provided. Waters under analysis come from the depth of ca. 200-2450 m in Lower Cretaceous and ca. 800-3400 m in Lower Jurassic formations. Not all samples were analysed in terms of microelements, especially iodides, iron and bromides presence.

For most of the wells, carrying out control field analysis is technically not feasible, mainly due to the fact that a significant number of them were abandoned, cemented or so on.

Calculations of theoretical wells discharge were carried out using Darcy-Dupuit formula, applied for infinite groundwater horizon exploited under stationary conditions (Paczyński et al. 1996; Pazdro and Kozerski 1990) using pre-prepared maps of hydrogeotherml parameters.

Calculations of potential discharges of hydrogeological wells assumed the optimum development modes of groundwater horizons. Therefore, calculated parameters were diversified within analysed aquifers under the following assumptions:

- Diameter of working part of screen in production well, $\Phi=2 * r=15 "(0.381 \mathrm{~m})$

- Drawdown during production will not exceed $100 \mathrm{~m}$

- Thickness of exploited groundwater horizon $m=100 \mathrm{~m}$ or thickness of groundwater horizons in the reservoir is equal to the working part of a screen.
$Q=2 \pi \times K \times m \times \frac{s}{\ln \frac{R}{r}}$,

where $Q$-discharge of production well $\left(\mathrm{m}^{3} / \mathrm{s}\right) ; K$-hydraulic conductivity $(\mathrm{m} / \mathrm{s}) ; m$ - thickness of groundwater horizon (limited by working length of screen) $(\mathrm{m}) ; s$-permissible drawdown (m); $r$-radius of production screen $(\mathrm{m}) ; R-$ radius of depression cone $(\mathrm{m})$.

Hydraulic conductivity was calculated according to the following formula (Paczyński et al. 1996; Pazdro and Kozerski 1990):

$K=\frac{k_{\mathrm{p}} \cdot(1-0.002 \cdot M) \cdot \rho_{\mathrm{w}} \cdot 9.81}{239.4 \cdot 10^{-7} \cdot 10^{\frac{248.37}{T_{\mathrm{s}}+133.15}}}$,

where $K$-hydraulic conductivity $(\mathrm{m} / \mathrm{s}) ; k_{\mathrm{p}}$-permeability $\left(\mathrm{m}^{2}\right) ; M$-mineralization of water $\left(\mathrm{kg} / \mathrm{m}^{3}\right) ; \rho_{\mathrm{w}}$-density of reservoir water $\left(\mathrm{kg} / \mathrm{m}^{3}\right) ; T_{\mathrm{s}}$-temperature of reservoir water $\left({ }^{\circ} \mathrm{C}\right)$.

Radius of depression cone was calculated with the Sichardt's formula (Paczyński et al. 1996; Pazdro and Kozerski 1990):

$R=3000 \times s \times \sqrt{K}$,

where $R$-radius of depression cone (m); $s$-drawdown (m); $K$-hydraulic conductivity $(\mathrm{m} / \mathrm{s})$.

Thermal power of possible geothermal installations is defined as follows (Górecki et al. 2006a, b):

$P=Q * \rho_{\mathrm{w}} * c_{\mathrm{w}} *\left(T-T_{\mathrm{i}}\right)(\mathrm{W})$,

where $Q$-rated discharge of geothermal water $\left(\mathrm{m}^{3} / \mathrm{s}\right) ; \rho_{\mathrm{w}}-$ density of geothermal water $\left(\mathrm{kg} / \mathrm{m}^{3}\right) ; c_{\mathrm{w}}$-specific heat of geothermal water $\left(\mathrm{J} / \mathrm{kg}{ }^{\circ} \mathrm{C}\right) ; T$-temperature of produced geothermal water $\left({ }^{\circ} \mathrm{C}\right) ; T_{\mathrm{i}}$-temperature of injected water (i.e. geothermal water after heat recovery) $\left({ }^{\circ} \mathrm{C}\right)$ (assumed $T_{\mathrm{z}}=25^{\circ} \mathrm{C}$ ).

Calculations of above-mentioned parameters were made taking into account the hydrogeological characteristics of the conditions of Lower Cretaceous and Lower Jurassic formations. Maps of potential discharge of wells and thermal power of a geothermal installation were constructed by superposition previously prepared maps (based on 25 wells).

\section{Results and discussion}

Analysed parameters come mostly from archival data of different quality. However, maps created on the basis of analysed parameters provide better visualisation of geothermal model approach of the area. They can be used for further analysis and preliminary determining prospective areas for geothermal purposes. 


\section{Thermal parameters}

Temperature of groundwaters in the top of the Lower Cretaceous reservoir under analysis depends on the depth of aquifer occurrence. In edge zones, temperature rarely exceeds $40{ }^{\circ} \mathrm{C}$; it grows towards central deepening of the Trough structure up to ca. $75^{\circ} \mathrm{C}$, and achieves maximum values north-east of Konin and south-west of Poddębice. In Lower Jurassic aquifer temperature is higher. The highest temperatures are recorded in the axial part of the Trough, where, locally, they exceed in the top of formation $100^{\circ} \mathrm{C}$. On the other hand, in edge Trough zones, water temperatures are $30-40{ }^{\circ} \mathrm{C}$ (Fig. 4).

\section{Physicochemical parameters}

Figure 5 presents distribution of water mineralisation from both Lower Cretaceous and Lower Jurassic formations, depending on the depth of sampled interval.

Waters from Lower Cretaceous formations have, on average, lower mineralisation than these from Lower Jurassic, 26.2 and $45.2 \mathrm{~g} / \mathrm{L}$, respectively. On the other hand,
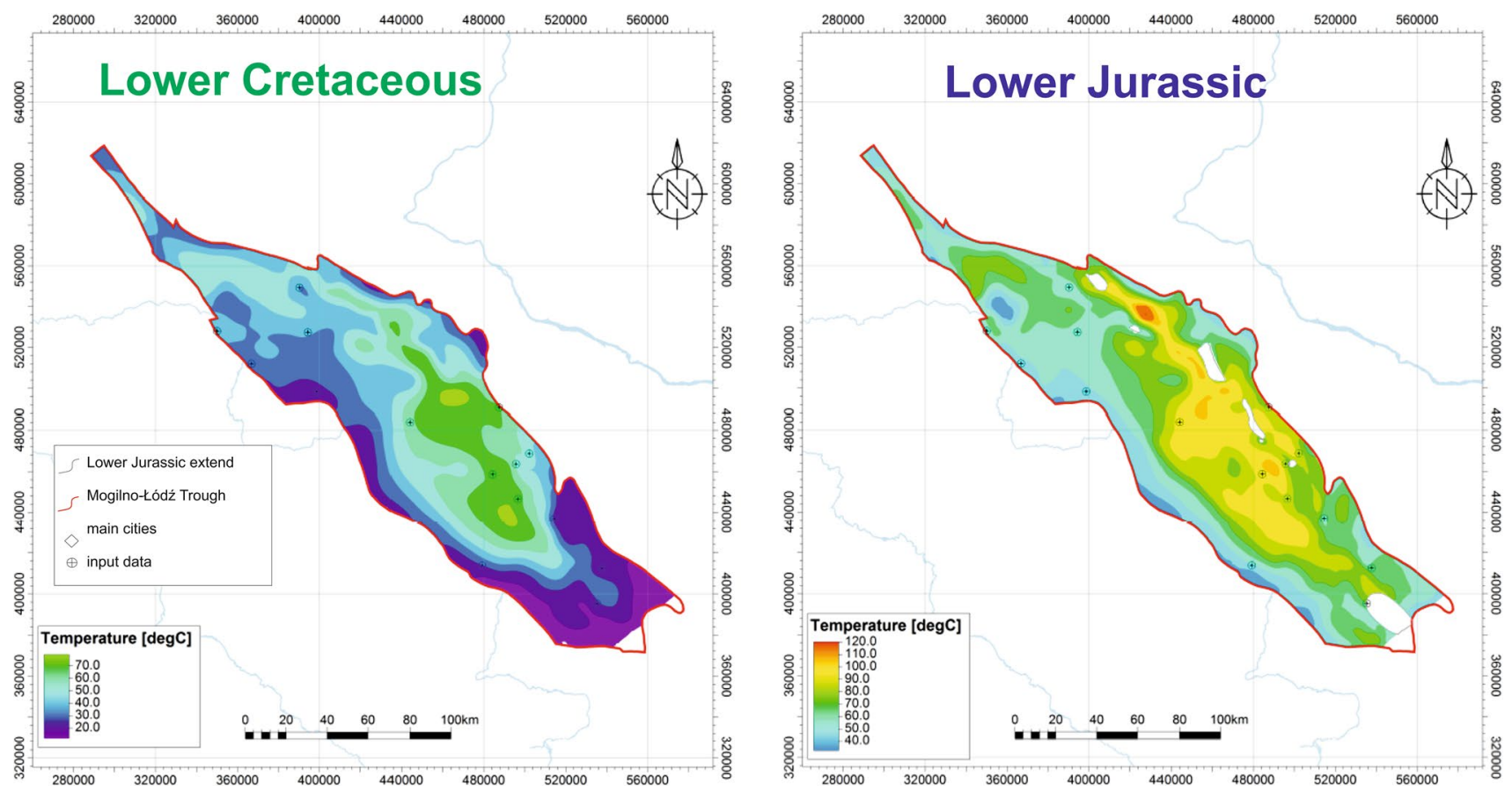

Fig. 4 Map of the potential temperature at the top surface of Lower Cretaceous and Lower Jurassic formations

Fig. 5 Diagram of dependence between mineralisation in $(\mathrm{g} / \mathrm{L})$ of water samples from Lower Cretaceous and Lower Jurassic formations and depth of the sampled interval [m below ground level]

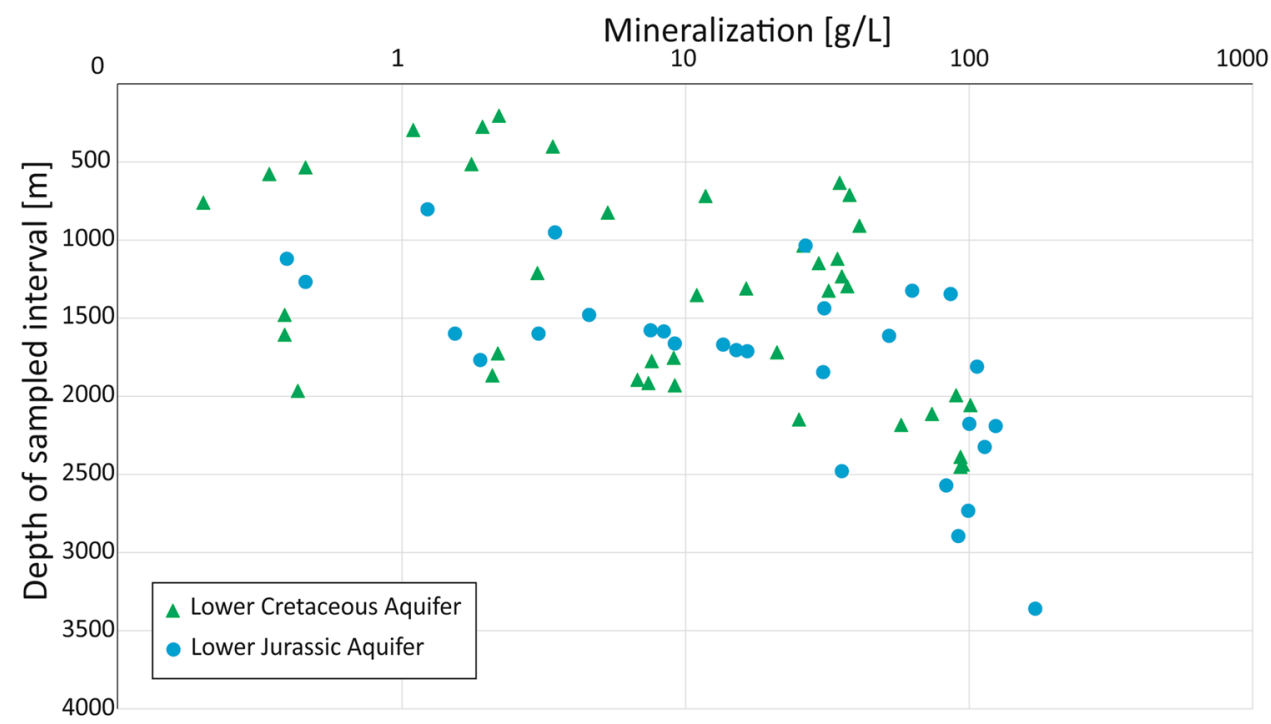


mineralization of Lower Jurassic waters, in principle, increases with depth; thus, when lack of data are observed, a kind of prediction of TDS due to hydrogeochemical gradient may be applied. In general, it would be said that Lower Jurassic aquifer is characterised with waters of higher mineralisation, contrary to the Cretaceous formations, with high variability and low of water mineralisation. Due to archival data and the fact that most of the wells are not operating, the reservoir understanding is sometimes incomplete. Lithological composition of both Lower Cretaceous and Lower Jurassic aquifers is highly variable. Water types other than $\mathrm{Na}-\mathrm{Cl}$ most likely occur in the southern, recharge zone. Influence on the physicochemical properties of waters can have both the presence of salt structures (i.a. $\mathrm{Na}-\mathrm{Cl}$ type) and the depth of occurrence which affects the quality of groundwater circulation (i.a. inflow of water from upper formations or mixing of waters) or the presence of tectonic dislocations.

\section{Lower Cretaceous Reservoir}

Mineralization of waters from Lower Cretaceous aquifer ranges from 0.2 to more than $100 \mathrm{~g} / \mathrm{L}$ (Fig. 5). The Lower Cretaceous formations consist generally of fine-grained sandstones and claystones or mudstones with siderite inserts or sandstones with claystone or mudstone inserts. A diagram in Fig. 6 shows the dependence of type of water from the depth of occurrence. Waters from deeper parts of the reservoir are usually of $\mathrm{Na}-\mathrm{Cl}$ type. Waters of $\mathrm{Na}-\mathrm{Cl}$ type occur in the central and northern (deeper) part of the area. In waters coming from smaller depths, and particularly, from the southern part of the Trough (close to a discharge zone), we can distinguish waters of $\mathrm{Na}-(\mathrm{Ca})-\mathrm{HCO}_{3}$ type, where mineralisation does not exceed $0.5 \mathrm{~g} / \mathrm{L}$. Sometimes (in 2 samples), $\mathrm{Na}-\mathrm{Cl}-\mathrm{HCO}_{3}$-type waters occur with mineralisation of ca. $2 \mathrm{~g} / \mathrm{L}$.
Waters with low mineralisation below $2 \mathrm{~g} / \mathrm{L}$ occur on a large area of the Trough, especially in its southern and western area. In the north-central and north-western part of the Trough, mineralisation increases up to the level of ca. $10-20 \mathrm{~g} / \mathrm{L}$. The highest mineralisation are observed in north-eastern, the edge part of the Trough, reaching even up to $100 \mathrm{~g} / \mathrm{L}$. In this part of the Trough, also high depths of Lower Cretaceous formations are observed. Waters from Lower Cretaceous formations sometimes demonstrate the presence of components important from the point of view of balneotherapeutic application like iron, iodides and bromides. Contents significant from the balneotherapeutic point of view occur in this area in waters at depths from ca. $1000 \mathrm{~m}$.

\section{Lower Jurassic Reservoir}

Values of water mineralisation in Lower Jurassic reservoir are much higher than in case of waters in Lower Cretaceous reservoir (Fig. 7). Mineralization of waters from Lower Jurassic aquifer ranges from 0.4 to over $170 \mathrm{~g} / \mathrm{L}$.

Maximum mineralisation values occur in the north-eastern and eastern parts of the Trough, where they are as high as over $150 \mathrm{~g} / \mathrm{L}$. The more to the south-west and to the south (recharge zones), the more mineralisation values decrease, reaching a dozen $\mathrm{g} / \mathrm{L}$. In the southern edge part, the mineralisation value is the lowest and it does not exceed several $\mathrm{g} / \mathrm{L}$.

The Lower Jurassic formations is built mostly from fine or medium grained sandstones with local claystones inserts and interbeds. Rarely there are siderite concretions or claystones and mudstones complexes.

The majority of waters are $\mathrm{Na}-\mathrm{Cl}$ waters. In few cases, especially in shallower Lower Jurassic formations, in the southern part of the Trough, there are multi-ion waters with low mineralisation, sometimes with $\mathrm{SO}_{4}$ or $\mathrm{HCO}_{3}$
Fig. 6 Box plot showing the dependence of types of water from the Lower Cretaceous and Lower Jurassic formations from depth of the sampled interval, K1-Lower Cretaceous, J1Lower Jurassic

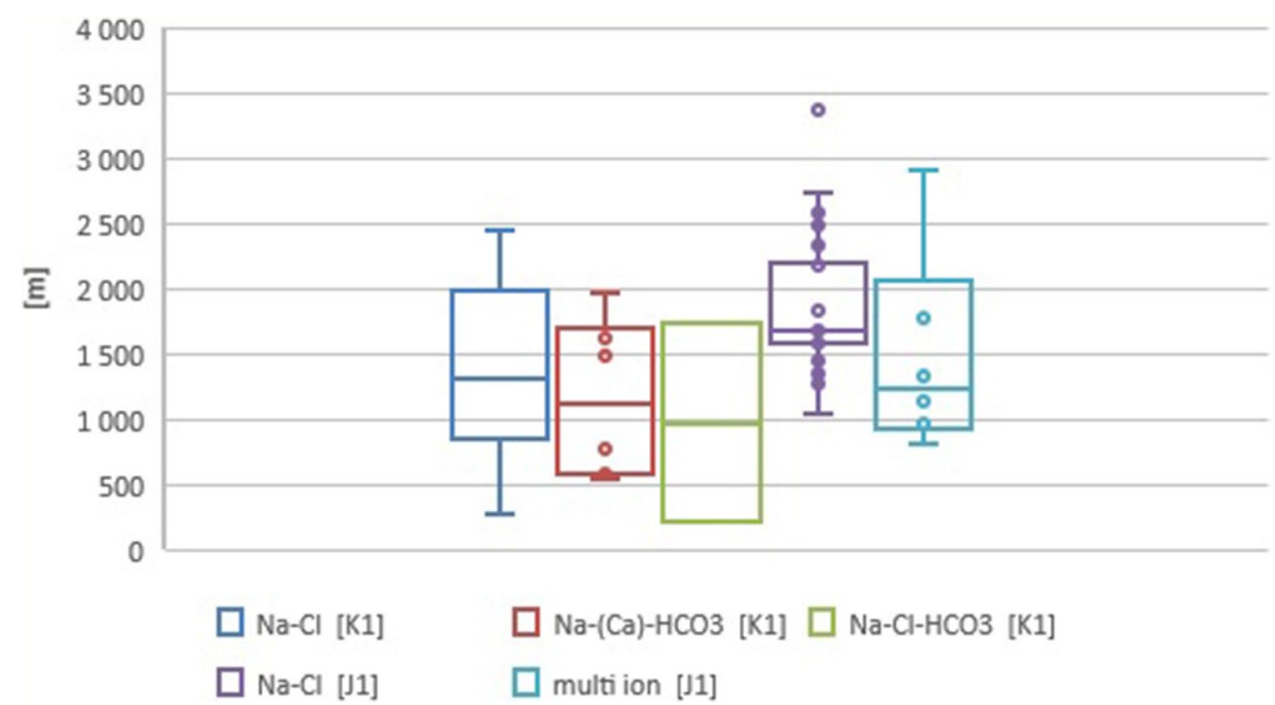



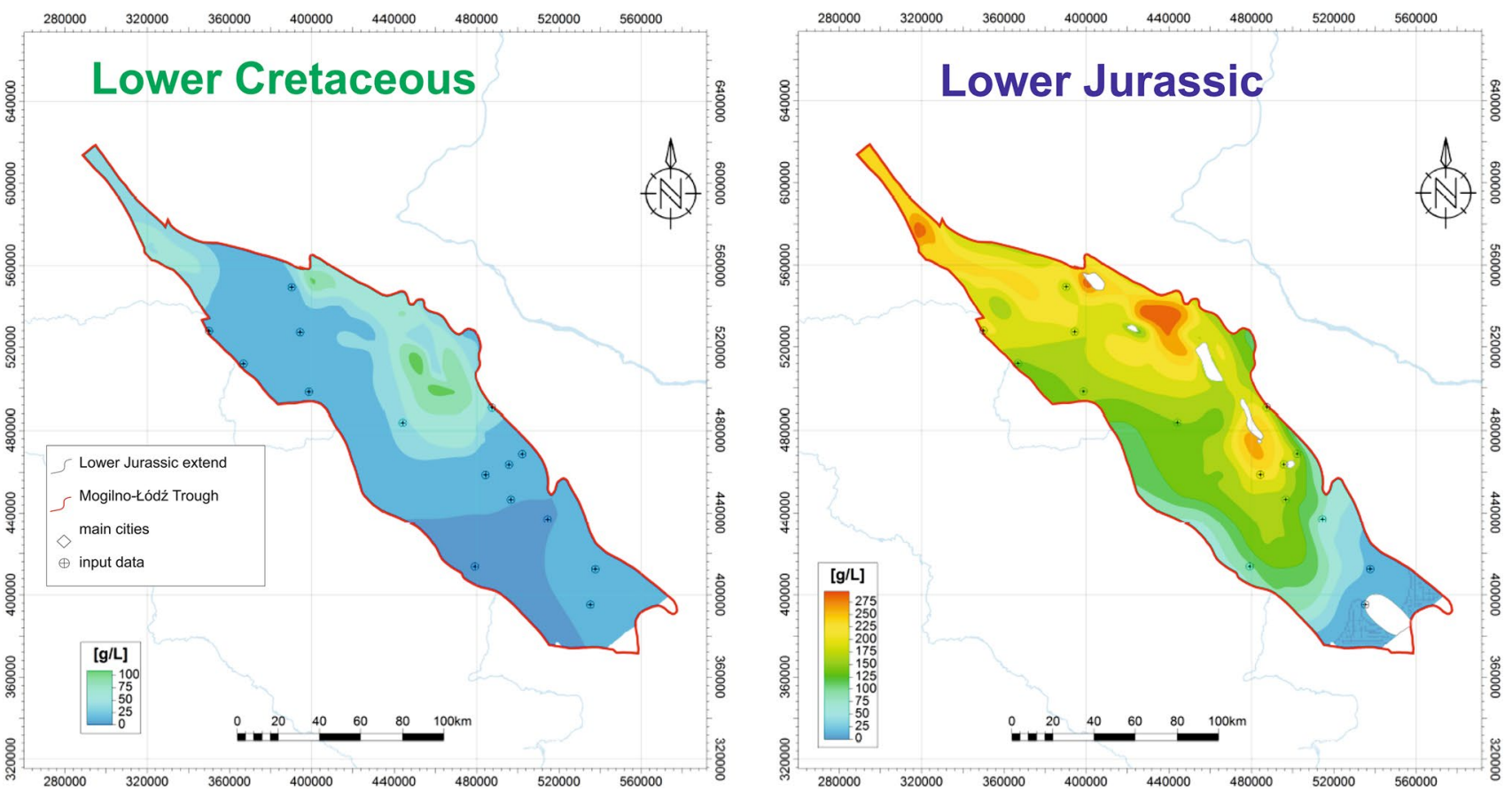

Fig. 7 Map of the potential mineralization at the top surface of Lower Cretaceous and Lower Jurassic formations

ions (Fig. 6). In several wells, waters contain higher quantities of magnesium or calcium. Waters from Lower Jurassic formations contain also iron, iodine and bromine ions.

In general, mineralisation increases proportionately with increase of depth and vertical water zonation is preserved. On the other hand, waters coming from the central and northern part of the trough have much higher mineralisation values than waters from similar depths, but coming from the southern part of the trough. Water mineralisation in the southern part of the trough rarely exceeds $20 \mathrm{~g} / \mathrm{L}$.

An interesting case, from chemical and thermal point of view, is water from Lower Cretaceous formations at great depth made available through Poddębice GT-2 well. A sampled interval is located at the depth of 1962-2063 m. Geothermal water at the outflow of the well is characterised with the temperature of ca. $71{ }^{\circ} \mathrm{C}$ and low mineralisation of $432 \mathrm{mg} / \mathrm{L}$, which is unusual for waters occurring in the vicinity area at a similar depths. The diagram in Fig. 8 shows the content of main water ions.

Water from Poddębice GT-2 well is of the $\mathrm{Na}-\mathrm{Ca}-\mathrm{HCO}_{3}$ type, which distinguishes it from among waters from the area, where waters of the $\mathrm{Na}-\mathrm{Cl}$ type prevail. Their mineralisation ranges from ca. 2-9 to 21-74 g/L, which is much higher than mineralization of freshwater from Poddębice GT-2 well. Moreover, water

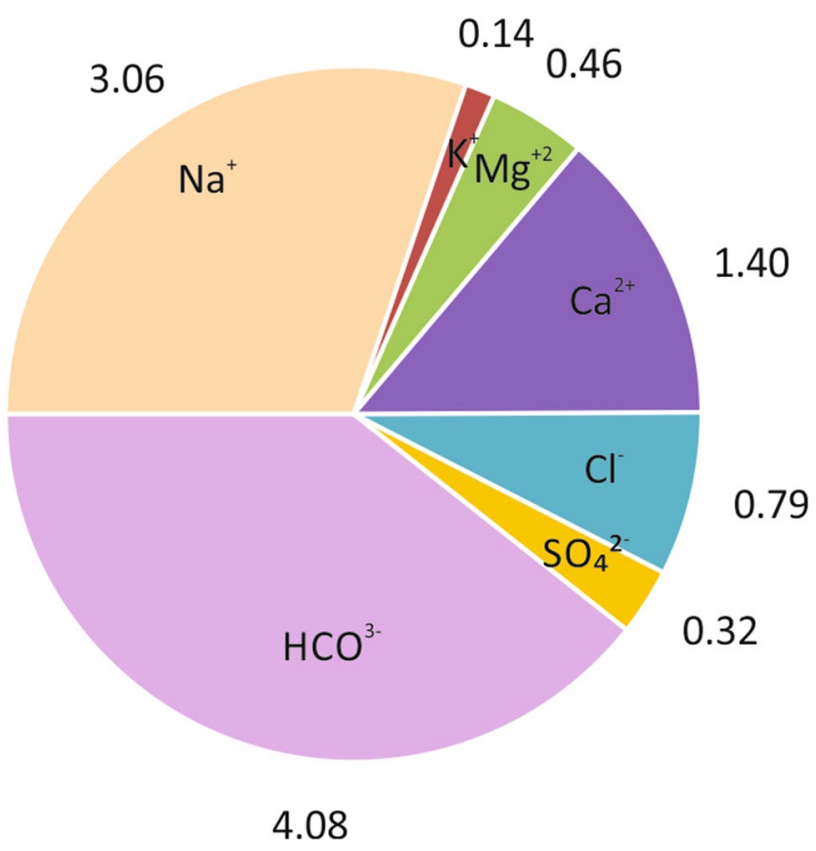

Fig. 8 Main ion contents of waters from Poddębice GT-2 well. Values in $\mathrm{meq} / \mathrm{L}$

from the well shows also a slight content of iron, iodine and bromine ions. 

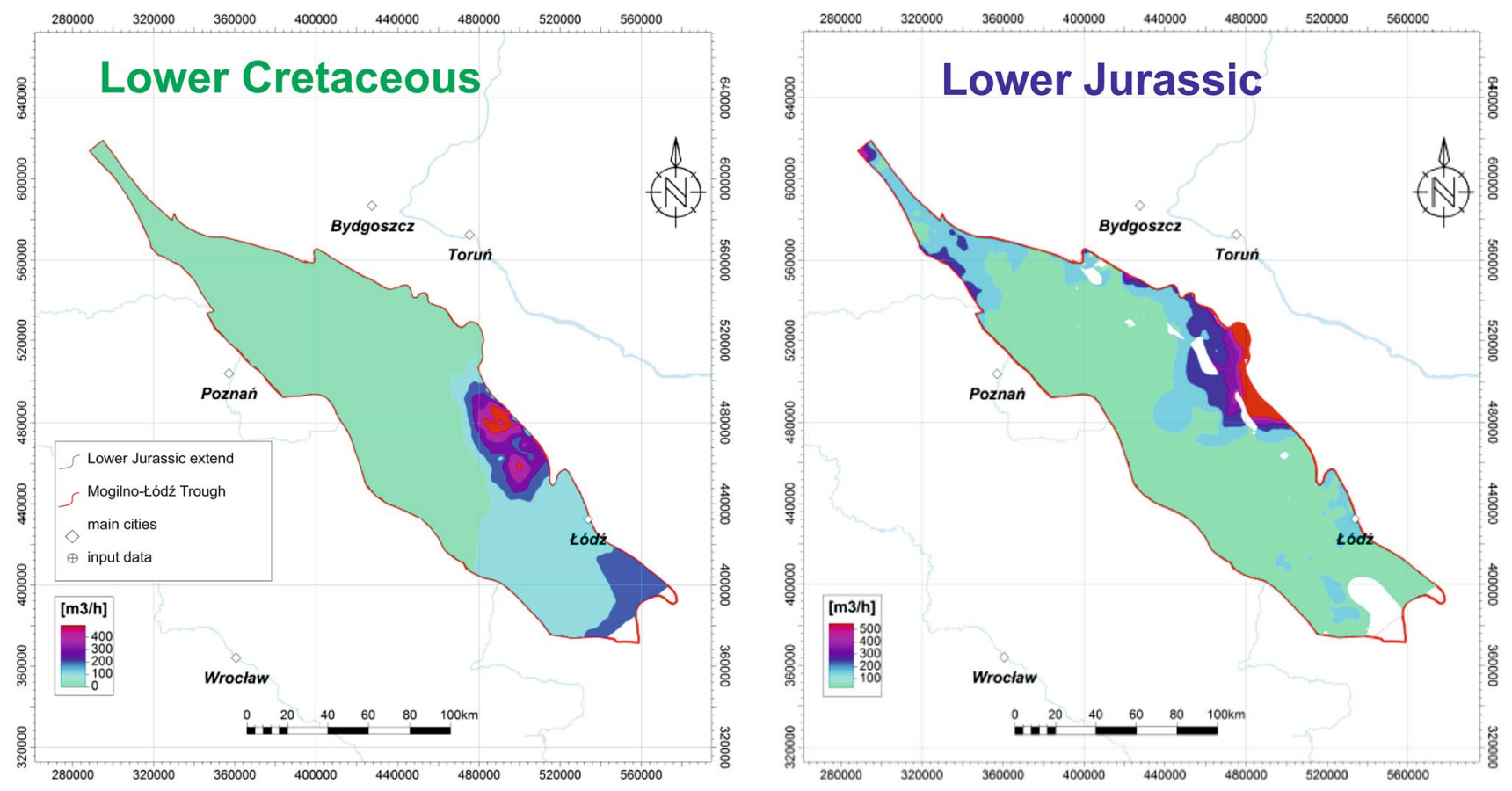

Fig. 9 Map of potential discharge of wells in Lower Cretaceous and Lower Jurassic reservoirs

\section{Potential discharge}

\section{Lower Cretaceous Reservoir}

A map of potential discharge rates (Fig. 9) in Lower Cretaceous reservoir indicates clearly that outflow over $50 \mathrm{~m}^{3} / \mathrm{h}$ should be expected only in the southern and south-eastern parts of the Trough. In the central and northern parts, the outflow drops below that value. The highest outflow values, even over $400 \mathrm{~m}^{3} / \mathrm{h}$, are expected in the area of north-eastern part of the Trough.

\section{Lower Jurassic Reservoir}

Potential discharge of wells for Lower Jurassic reservoir is variable from several dozen up to even $500 \mathrm{~m}^{3} / \mathrm{h}$. Considerable outflow growth is observed towards the east. Locally, such high outflow values can be expected also in the northern part of the area, although the highest outflow can be expected in the eastern part of the stud area, particularly in the area of north-eastern part of the Trough (even over $400-500 \mathrm{~m}^{3} / \mathrm{h}$ ) (Fig. 9).

\section{Thermal power}

\section{Lower Cretaceous Reservoir}

A strong impact of that parameter upon the anticipated geothermal installations parameters can be seen on the map of the potential thermal power of geothermal installations within Lower Cretaceous reservoir in the area of Mogilno-Lódź Trough. In a vast part of the area under analysis, potential geothermal installations will not exceed the power of $5 \mathrm{MW}$. Yet, the eastern part of the Trough should be paid attention to, where, in the zone extending from Poddębice to the north, a possibility of setting up a geothermal installations with capacity over $5 \mathrm{MW}$ or even over $20 \mathrm{MW}$ is contemplated.

\section{Lower Jurassic Reservoir}

The above-mentioned distribution of hydrogeothermal parameters of Lower Jurassic reservoir is reflected in the values of geothermal resources and in the distribution of the expected thermal power for geothermal installations in the study area. Special attention should be drawn particularly to the eastern part of Mogilno-Łódź Trough, where, similarly to Lower Cretaceous reservoir, a possibility of building geothermal installations with power over $5 \mathrm{MW}$ is anticipated. Locally, such zones can be found also in the northern and southern parts of the Trough, although their range is much smaller than in the eastern part, and expected power do not exceed $15 \mathrm{MW}$. In the most prospective eastern region, one can expect geothermal installations with power ranging from 10 to $30 \mathrm{MW}$, and, locally, even over $40 \mathrm{MW}$ (Fig. 10).

The analysed geothermal reservoirs are characterised by favourable hydrogeothermal parameters (Table 1). An important feature is high discharge of wells, reaching several hundred $\mathrm{m}^{3} / \mathrm{h}$, possible to obtain from both Lower Cretaceous (K1) 

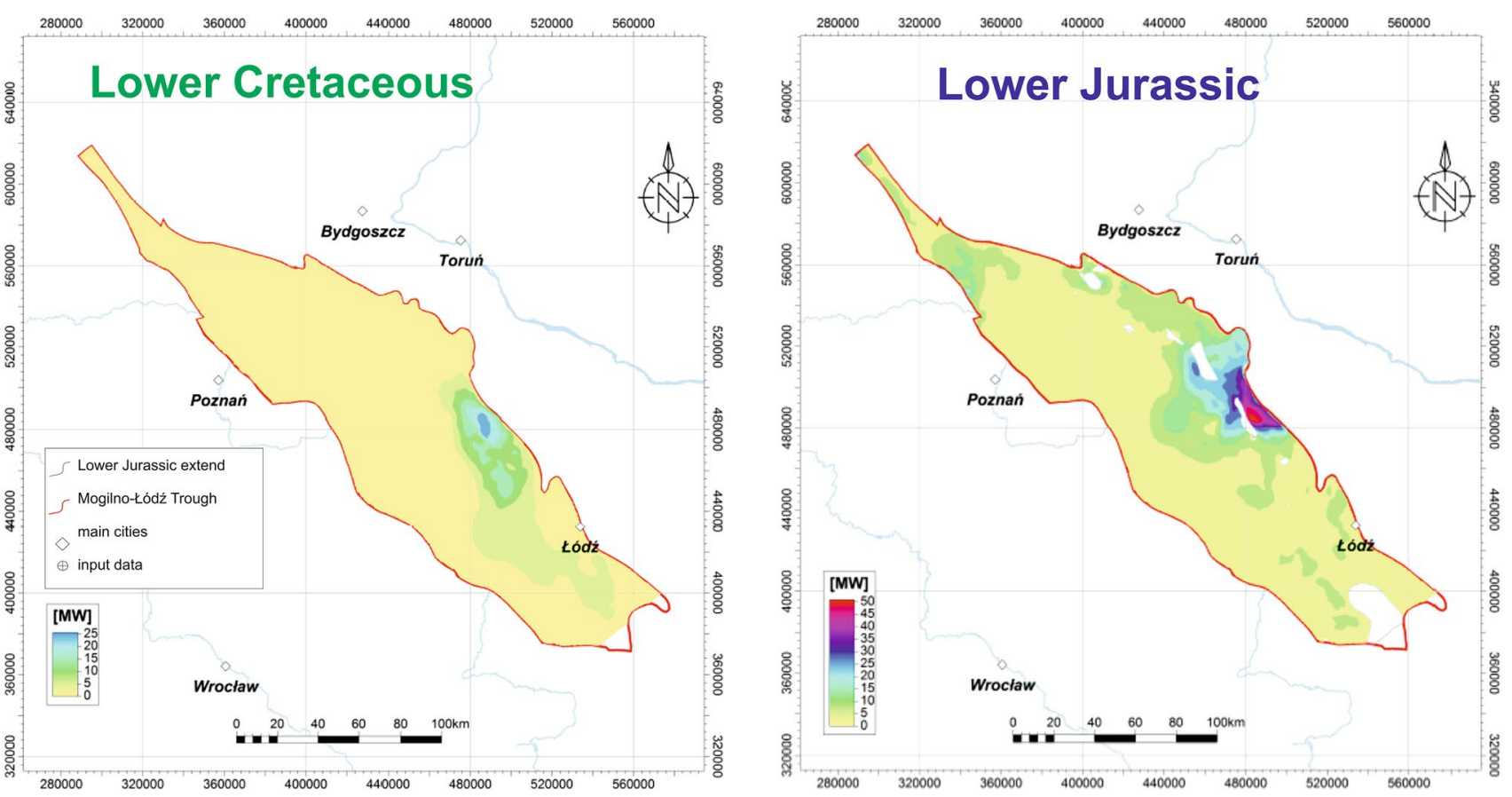

Fig. 10 Map of thermal power of a geothermal installation developed in Lower Cretaceous and Lower Jurassic reservoirs

Table 1 Summary of geological and hydrogeological parameters of Lower Cretaceous and Lower Jurassic reservoir in the region of the Mogilno-Eódź Trough

\begin{tabular}{|c|c|c|c|c|c|c|}
\hline $\begin{array}{l}\text { Geo- } \\
\text { thermal } \\
\text { reservoir }\end{array}$ & $\begin{array}{l}\text { The depth of } \\
\text { the top (m } \\
\text { b.g.l.) }\end{array}$ & The thickness of reservoir $(\mathrm{m})$ & $\begin{array}{l}\text { Miner- } \\
\text { alization } \\
(\mathrm{g} / \mathrm{L})\end{array}$ & $\begin{array}{l}\text { Temperature at the top } \\
\text { of reservoir }\left({ }^{\circ} \mathrm{C}\right)\end{array}$ & $\begin{array}{l}\text { Potential dis- } \\
\text { charge of wells } \\
\left(\mathrm{m}^{3} / \mathrm{h}\right)\end{array}$ & $\begin{array}{l}\text { The most } \\
\text { common } \\
\text { types of } \\
\text { water }\end{array}$ \\
\hline K1 & To over 2500 & From a few to around 400 (locally up to 600 ) & ca. 100 & Max. 75 & To over 400 & $\begin{array}{l}\mathrm{Na}-\mathrm{Cl} \\
\mathrm{Na}-(\mathrm{Ca})- \\
(\mathrm{Cl})- \\
\mathrm{HCO}_{3}\end{array}$ \\
\hline $\mathrm{J} 1$ & Max. 3750 & $\begin{array}{l}\text { From a few to around } 200-250 \text { (up to around } \\
850 \text { ) }\end{array}$ & ca. 170 & Locally up to over 100 & To over 500 & $\mathrm{Na}-\mathrm{Cl}$ \\
\hline
\end{tabular}

and Lower Jurassic (J1) reservoirs. Waters of Lower Cretaceous reservoir are characterised by lower temperatures (up to $75^{\circ} \mathrm{C}$ ), whilst waters of Lower Jurassic reservoir up to $100^{\circ} \mathrm{C}$. Furthermore, waters of Lower Jurassic aquifer are characterised by high mineralization, which even exceeds $100 \mathrm{~g} / \mathrm{L}$.

\section{Conclusions}

Considering geological conditions in the Polish Lowland, geothermal exploration aims at obtaining waters with highest outlet temperature, maximum artesian outflow and low mineralisation. The results of the analysis indicate that in the area of Mogilno-Łódź Trough, a significant untapped geothermal potential still exist. Higher energy potential relates to waters of Lower Jurassic reservoir; however, when it comes to using them, one should bear in mind its high water mineralisation, causing the need of reinjection using doublets or more efficient multi-well systems.

The Lower Jurassic reservoir has good prospectives for direct use of geothermal waters, mainly for heating purposes in large area. While in the Lower Cretaceous good parameters occur in a rather limited area. However, it is worth to emphasise that Lower Cretaceous waters are characterised by lower mineralisation and occasionally they might even be used as drinking water.

At the stage of geological and geothermal models preparation, all available: geological, hydrogeological and geothermal - both qualitative and quantitative data, concerning deep geological profile in the study area, were used. Further research for improvement of the quality of the models is possible through extension of the input database or/and changing the concept of data interpretation. 
The studies carried out recently indicate that the actual geothermal potential in the area of Mogilno-Łódź Trough is much higher compared to that currently being used. Many municipalities located in this area still have an opportunity to use this renewable and ecological energy source for heating, balneotherapy and other purposes.

Acknowledgements The article was elaborated in the framework of the Project "Geothermal energy_a basis for low-emission heating, improving living conditions and sustainable development-preliminary studies for selected areas in Poland" co-funded by the Financial Mechanism of the European Economic Area (EEA) 2009-2014, as part of the Bilateral Co-operation Fund, PL04 Programme "Energy saving and promotion of renewable energy sources" and AGH University of Science and Technology statutory work No. 16.16.140.315.

Open Access This article is licensed under a Creative Commons Attribution 4.0 International License, which permits use, sharing, adaptation, distribution and reproduction in any medium or format, as long as you give appropriate credit to the original author(s) and the source, provide a link to the Creative Commons licence, and indicate if changes were made. The images or other third party material in this article are included in the article's Creative Commons licence, unless indicated otherwise in a credit line to the material. If material is not included in the article's Creative Commons licence and your intended use is not permitted by statutory regulation or exceeds the permitted use, you will need to obtain permission directly from the copyright holder. To view a copy of this licence, visit http://creativecommons.org/licenses/by/4.0/.

\section{References}

Bujakowski W, Tomaszewska B et al (2014) Atlas of the possible use of geothermal waters for combined production of electricity and heat using binary system in Poland. MEERI PAS, Krakow

Central Geological Database (CBDG). Polish Geological InstituteNational Research Institute. http://baza.pgi.gov.pl/. Accessed 27 June 2019

Dadlez R, Marek S, Pokorski J (2000) Geological map of Poland without Cenozoic formations, 1: 1000 000. Polish Geological Institute, Warsaw (in Polish)

Górecki W, Hajto M et al. (2011) Atlas of geothermal waters and energy resources in the Western Carpathians. Ministry of Environment. Akademia Górniczo-Hutnicza im. Stanisława Staszica w Krakowie. Wydział Geologii, Geofizyki i Ochrony Środowiska. Zakład Surowców Energetycznych, Krakow

Górecki W, Hajto M et al (2006a) Atlas of geothermal resources of Mesozoic formations in the Polish Lowlands. AGH, Krakow

Górecki W, Hajto M et al (2006b) Atlas of geothermal resources of Paleozoic formations in the Polish Lowlands. AGH, Krakow

Górecki W, Sowiżdżał A et al (2012) Geothermal Atlas of the Carpathian Foredeep. AGH KSE, Krakow (in Polish)

Górecki W, Hajto M et al (2013) Geothermal atlas of the eastern Carpathians. AGH KSE, Krakow

Górecki W, Sowiżdżał A, Hajto M, Wachowicz-Pyzik A (2015) Atlases of geothermal waters and energy resources in Poland. Environ Earth Sci 74(12):7487-7495. https://doi.org/10.1007/s12665-014-3832-2

Haenel R, Hurter S (2002) Atlas of geothermal resources in Europe. Commission of the European Communities, Brussels

Halaj E (2015) Geothermal bathing and recreation centres in Poland. Environ Earth Sci 74:7497-7509. https://doi.org/10.1007/s1266 5-014-3740-5
Halaj E (2017) Characteristics and sustainable utilization prospects of geothermal waters of the liassic formations in the MogilnoLodz Trough, Poland. Sustain Water Resour Manag. https://doi. org/10.1007/s40899-018-0235-7

Halaj E, Kepinska B (2018) Conjunctive uses of the geothermal water resources from lower cretaceous formations in the MogilnoLodz Trough, Poland. Sustain Water Resour Manag. https://doi. org/10.1007/s40899-018-0284-y

Karnkowski P (1980) Deep geological cross-sections of the Polish Lowlands. Wyd. Geologiczne, Warsaw (in Polish)

Kępińska B, Pająk L, Bujakowski W, Kasztelewicz A, Hajto M, Sowiżdżał A, Pétursson B, Tulinius H, Thorgilsson G, Einarsson ÓP, Karska A, Peraj A (2017) Geothermal utilization potential in Poland: the town of Poddębice Part 1. Selected reservoir and exploitation aspects of current and further geothermal district heating and other uses' development in Poddębice. Technika Poszukiwań Geologicznych Geotermia, Zrównoważony Rozwój 1:3-20

Maćkowski T, Sowiżdżał A, Wachowicz-Pyzik A (2019) Seismic methods in geothermal water resource exploration: case study from Łódź trough, central part of Poland. Geofluids. https://doi. org/10.1155/2019/3052806

Mizerski W (2011) Geology of Poland. PWN, Warsaw (in Polish)

Narkiewicz M, Dadlez R (2008) Geological regionalization of Poland: general rules and scheme of division in undercenozoic and underpermian plain. Geol Rev 56:5

Paczyński B, Macioszczyk T, Kazimierski B, Mitręga D (1996) Disposable ground water resources determination: methodological guidebook. Wyd. TRIO, Warsaw (in Polish)

Pazdro Z, Kozerski B (1990) Hydrogeology. Wyd. Geologiczne, Warsaw (in Polish)

Posyniak A (2015) Annex no. 1 to Hydrogeological documentation establishing exploitation reserves of thermal water intake "Poddębice GT-2" from Lower Cretaceous formation in Poddębice. Archives Geothermal Poddębice Sp. z o.o., Warsaw (in Polish)

Sapińska-Śliwa A (2011) Thermal waters of Uniejow in terms of interpretation of hydrodynamic indicators. Wiertnictwo Nafta Gaz 28(1-2):359-369

Sowiżdżał A (2018) Geothermal energy resources in Poland: overview of the current state of knowledge. Renew Sustain Energy Rev 82(3):4020-4027

Sowiżdżał A, Kaczmarczyk M (2016) Analysis of thermal parameters of Triassic, Permian and Carboniferous sedimentary rocks in central Poland. Geol J 51(1):65-76

Sowiżdżał A, Papiernik B, Machowski G, Hajto M (2013) Characterization of petrophysical parameters of the Lower Triassic deposits in prospective location for enhanced geothermal system (central Poland). Geol Q 57(4):729-744

Sowiżdżał A, Hajto M, Papiernik B, Mitan K, Halaj E (2017) Possibilities of geothermal sector development in central Poland in reference to extended structural and parametrical analysis of Mogilno-Łódź Trough. Geol Explor Technol Geotherm Energy Sustain Dev 56(2): 17-31

Sowiżdżał A, Maćkowski T, Wachowicz-Pyzik A (2019) Recognition of Lower Cretaceous geothermal potential of Central Poland with the application of geophysical methods. Sustain Water Resour Manag. https://doi.org/10.1007/s40899-019-00309-2

Stupnicka E (1997) Regional geology of Poland. Wyd. Uniw. Warsz, Warsaw (in Polish)

Wójcicki A, Sowiżdżał A, Bujakowski W et al. (ed.) (2013) Evaluation of potential, thermal balance and prospective geological structures for needs of closed geothermal systems (Hot Dry Rocks) in Poland. Warsaw (in Polish)

Publisher's Note Springer Nature remains neutral with regard to jurisdictional claims in published maps and institutional affiliations. 